\title{
Phytotherapeutic Interventions using Rodent Models of Hair Loss: Current Research and Future Strategy
}

\author{
P. S. JOSHI*, Y. B. PATIL ${ }^{1}$, TANIA S. PAUL ${ }^{2}$ AND KISHORI G. APTE ${ }^{2}$ \\ Symbiosis School of Biological Sciences, Symbiosis International (Deemed University), Pune, Maharashtra 412115, \\ ${ }^{1}$ Symbiosis Centre for Research and Innovation, Symbiosis International (Deemed University), Pune, Maharashtra 412115, \\ ${ }^{2}$ APT Research Foundation, Pune, Maharashtra 411041, India
}

Joshi et al.: Phytotherapeutic Interventions using Rodent Models of Hair Loss

\begin{abstract}
Hair follicles are special additions to mammalian skin with intricate differentiation and growth characteristics. They constantly undergo cycles of regression and regeneration throughout the lifespan of animal. Several rodent models have been studied for androgenetic alopecia and alopecia areata in humans with only handful of products approved by United States Food and Drug Administration; topical minoxidil (men and women) and oral finasteride (only men) for hair loss indication. This review summarizes rodent models of human hair loss to emphasize their role in testing traditional medicinal plants as hair growth promoters. Review also discusses the mechanisms of action of various herbs. Currently, both natural and synthetic products are in use to remedy alopecia. Although, use of natural products has shown measurable efficacy, the option is open to test chemically synthesized active fractions of plants as monotherapy or polytherapy to facilitate approval by regulatory agencies. Overall, purpose of this review is to discuss the rodent models of efficacy and how modifications in herbal preparations may bring more alternatives and a better value to the products in future.
\end{abstract}

Key words: Minoxidil, finasteride, rodent models, herbal preparations

Hair, a specialized appendage on body has evolved in most mammalian species as a means of protection of skin and a mode of communication via signals and cues. The outer surface of the body and limbs is covered by the epidermis, which is expanded into numerous hair follicles ${ }^{[1]}$. Hair follicles are dynamic structures owing to their growth and differentiation characteristics. After birth, mature hair follicles undergo cycles of anagen, catagen and telogen phases in a repetitive manner ${ }^{[2]}$. Major signaling molecules such as bone morphogenic protein receptor, epidermal growth factor receptor, fibroblast growth receptor 2, insulin - like growth factor 1 receptor, and fibroblast growth factor (FGF) 7 have been implicated in hair growth pattern and overall hair cycle turnover based on studies conducted using mutant mouse models of hair loss ${ }^{[3]}$. Mink skin tissues were used to demonstrate an antagonistic interaction between FGF 10 and secreted frizzledrelate protein-1 (sFRP1), both competitively regulate $\beta$-catenin pathway ${ }^{[4]}$. Such studies have shed light on genes potentially associated with similar human hair loss disorders. The quest is ongoing to understand and unravel putative mechanisms underlying different

*Address for correspondence

E-mail: pramodjoshi02@yahoo.com

September-October 2020 patterns of human hair loss by studying animal models ${ }^{[1]}$. Alopecia areata (AA) universalis is an autoimmune disorder that is manifested by malfunctioning of anagen phase including miniaturization of the hair follicles ${ }^{[5-7]}$. Inhibitors of Janus kinase (JAK) family protein tyrosine kinases such as ruxolitinib and tofacitinib promote rapid hair regrowth in AA in mice and humans ${ }^{[8]}$. Anagen phase dysfunction has been shown in androgenetic alopecia (AGA) (male pattern baldness) as well that is plausibly caused by the effects of dihydrotestosterone on genetically predisposed hair follicles in humans ${ }^{[9]}$. Therefore, scientific community is facing challenges to devise pharmacologically active agents that would enable hair cycle resumption already ceased in AGA. Although, minoxidil and finasteride are the only United States Food and Drug Administration (USFDA) approved products for AGA, scientists have

This is an open access article distributed under the terms of the Creative Commons Attribution-NonCommercial-ShareAlike 3.0 License, which allows others to remix, tweak, and build upon the work non-commercially, as long as the author is credited and the new creations are licensed under the identical terms

Accepted 15 September 2020

Revised 05 September 2020

Received 31 March 2020

Indian J Pharm Sci 2020;82(5):781-790 
raised questions on their efficacy ${ }^{[10]}$. In addition, no USFDA-approved therapy exists for $\mathrm{AA}^{[11]}$.

The research to date using herbal compounds has not yielded additionally approved synthetic remedies that can combat alopecia in humans. Natural products have been proven to be source of leads for the development of drugs such as anti-cancer agents (ixabepilone and daptomycin) and anti-infectives (tigecycline and telithromycin) and, multitude of molecular biology, chemistry, and data mining approaches are aiding to create screening libraries for drug-like compounds ${ }^{[12]}$. Despite a number of clinical trials were conducted using natural products for hair loss indication, none of those products advanced to end up as approved drug products ${ }^{[11]}$. Considering researchers adopting a conventional methodology of testing racemic mixtures of different herbs in rodent models, it may be prudent to narrow down research to a level of single synthetic small molecule entity (for potential use as monotherapy or polytherapy) based on structural read outs from herbal mixtures that may enable higher probability of expanding drug pipeline for hair loss indication. Understanding mechanisms of action is one part however; establishing proof of concept in rodent model will be a critical step towards further downstream development. Generating a small molecule in a synthetic way from herbal mixture may be considered a key step to drive the drug discovery and development efforts than the natural compound getting investigated further as a potential remedy when patients are expected to receive treatment for longer duration for certain types of alopecia. The present review paper attempts to recapitulate existing preclinical research in the area of rodent efficacy models of hair loss that utilized diverse herbal preparations and emphasizes the importance of developing novel small synthetic molecules from existing natural compounds to streamline the approval process by regulatory authorities.

\section{METHODOLOGY}

The research databases such as PubMed, Scopus, Research Gate, Google, ScienceOpen, and SpringerLink were searched for the articles published from 1949 to present. Search terms included "animal models of hair loss", "rodent models of hair loss", "herbal products for hair loss", "herbal therapy for hair loss", and "topical herbal preparations for hair loss." References mentioned in different reviews on herbal products and hair loss were searched for additional publications.

\section{Animal models:}

Research on animal models of human hair loss disorders started nearly seven decades ago ${ }^{[13]}$. Considering only two USFDA approved drugs for human hair loss (minoxidil and finasteride) and third repurposed drug, dutasteride for men's hair loss approved in South Korea and $\mathrm{Japan}^{[14]}$, the pursuit for novel, and efficacious hair growth promoting agents increased considerably.

Hamsters, rabbits, rodents and sheep have been used to conduct in vivo studies on hair loss and regeneration ${ }^{[13]}$. The Mesocricetus auratus (golden hamster) was used for macroscopic assessment (hair density analysis) and microscopic evaluation (hair diameter analysis) as an animal model for hair re-growth ${ }^{[15]}$. Minoxidil (5\% solution) when applied topically on frontal bald scalp of stump-tailed macaques, demonstrated hair regrowth in AGA model ${ }^{[16]}$.

In general, rodent species exemplify as suitable model to study human hair loss. Mouse has short hair cycle $(3 \mathrm{w})$ with well demarcated phases (anagen segmented into six and catagen into eight sub phases ${ }^{[17]}$. There are no structural differences between mouse and human hair cycles except catagen phase in mouse shows hair bulb alterations without retraction of vibrissae follicles ${ }^{[1]}$. Rat model has ability to transform human stem cells into dermal papilla thereby culminating into formation of new hair follicles ${ }^{[18]}$.

$\mathrm{C} 3 \mathrm{H} / \mathrm{HeJ}$ mice and Dundee Experimental Bald Rat (DEBR) models are the foundation of developing new treatments for $\mathrm{AA}^{[19-21]}$. The pigmented rodents such as C57BL/6 mice were used for studying new anagen regrowth in context of skin-free pigment and early visible pigmented tips ${ }^{[22]}$. Laser therapy, when applied for $20 \mathrm{~s} / \mathrm{d}, 3$ times per $\mathrm{w}$ for $6 \mathrm{w}$ in $\mathrm{C} 3 \mathrm{H} / \mathrm{HeJ}$ mouse, induced a much longer growth phase, after only $2 \mathrm{w}$ of treatment, with most of the hair follicles in anagen phase from the tested area ${ }^{[23]}$. Immunodeficient hairless outbred mice have been successfully used for development of chemotherapy induced alopecia mode ${ }^{[24]}$. Keratin 5-human androgen receptor transgenic mice have been effectively tested in AGA model ${ }^{[25]}$. Patterned hair growth was studied in wild type rats and mice ${ }^{[26]}$. Human xenografts have the potential for grafting skin onto immunodeficient severe combined immunodeficiency mice ${ }^{[27]}$. Chrysanthemum zawadskii var. latilobum (Asteraceae) (CZ) stimulated hair growth in athymic nude mice by repairing nu/nu follicular keratin differentiation defect ${ }^{[28]}$. A similar efficacy was previously demonstrated in athymic nude 
mice after using Eclipta alba extract ${ }^{[29]}$. Hair follicle bulge cells possess stem cell characteristics with a resemblance between human and mouse cells based on proliferation studies of human scalp grafted to immunodeficient mice $^{[30]}$.

It has been shown that topical minoxidil intervenes the normal hair cycle by shortening telogen phase, causing premature entry of the resting follicles into anagen phase thus, leads to an increased hair follicle size ${ }^{[31]}$. Finasteride on the other hand is currently marketed for AGA indication in men and acts as 5 - $\alpha$-reductase inhibitor ${ }^{[32]}$. Efficacy of finasteride and minoxidil are debatable ${ }^{[10]}$. Considering scarcity of approved remedies available for alopecia, an immense potential exists to expand products list. The extensive body of literature on mouse studies have already provided the evidence of genes underlying numerous human disorders, and mouse hair loss mutants are likely to benefit our understanding of human hair loss, thereby broadening our knowledge of mechanisms controlling morphogenesis ${ }^{[1,3]}$ to invent better hair growth promoting agents.

\section{Herbal Agents:}

Preclinical research plays a vital role in evaluating proof of concept for any disease indication. As far as hair loss is concerned, scientists across globe have published abundant literature on herbs and their efficacious effects on rodent models of hair loss (Table 1). Rodent studies have shown beneficial effects of hair growth using herbal plants such as, $3 \%$ proanthocyanidins from grape seeds $(\mathrm{C} 3 \mathrm{H} \text { mouse })^{[33]}$, Panax ginseng extract and ginsenoside Rb1 (mouse vibrissal follicles in organ culture) ${ }^{[34]}$, Polygonum multiflorum extract (C57BL/6 mice $)^{[35]}$, Nardostachys jatamansi extract and their constituents (nardal, jatamansic acid, wistar rats) ${ }^{[36]}$, Citrullus colocynthis Schrad extract (albino mice) ${ }^{[37]}$, and Ziziphus jujuba oil (BALB/C mice) $)^{[38]}$. Eclipta alba extract ( 2 and $5 \%$ ) incorporated into water in oil cream base showed a better hair growth activity than $2 \%$ topically applied minoxidil on skin of shaved rats $^{[39]}$.

Herbal formulations are not always superior to standard of care and some rodent studies indicated that herbal formulation or minoxidil had similar biological activity for hair growth. Petroleum ether Tectona grandis seeds extract ( 5 and $10 \%$ ) in ointment base displayed similar increases in hair follicles in anagen phase when compared with standard of care minoxidil after 30 days of treatment in albino mice ${ }^{[40]}$. Lotion oil in water type base with $30 \%$ of Nicotiana tabaccum extract ${ }^{[41]}$ were equivalent in hair growth promotion as $2 \%$ minoxidil.

Most topical herbal preparations produce stimulatory effect of hair growth promotion ${ }^{[42]}$ with exception of 6-gingerol (containing main active constituent Zingiber officinale) that exerted proapoptotic effects on dermal papilla cells in vitro and caused prolongation of telogen phase in vivo resulting in hair growth inhibition ${ }^{[43]}$.

Overall, herbal formulations have been proven to be efficacious in rodent models to promote hair growth.

\section{Mechanisms of Action:}

The molecules of interest associated with hair growth modulation are divided into two broad categories; hair growth stimulatory molecules that include Wnt/ $\beta$-catenin, prostaglandin E (PGE), prostaglandin F (PGF), insulin-like growth factor-1 (IGF-1), vascular endothelial growth factor (VEGF), epidermal growth factor (EGF), and FGF-2 and FGF-7 while, hair growth inhibitory molecules include transforming growth factor beta (TGF- $\beta$ ), FGF-5, $5 \alpha$-reductase, dihydrotestosterone (DHT), and prostaglandin D2

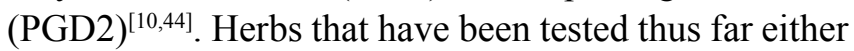
showed hair growth stimulation by upregulating hair growth stimulatory molecules or they inhibited hair growth inhibitory molecules to result in hair growth promotion (Table 1). Examples of phyto constituents responsible for hair growth promoting activity are mentioned in Table 2.

FGF family are critical in human hair follicle development, epidermal differentiation and proliferation $^{[45]}$. FGF-2 and FGF- 7 (identified as Keratinocyte growth factor (KGF)) positively stimulate the hair growth cycle of mice ${ }^{[46]}$ while FGF-5 acts as an inhibitor of hair growth during anagen phase $\mathrm{e}^{[47]}$. Lycopene isolated from rice bran supercritical $\mathrm{CO}_{2}$ extract and other major components (linoleic acid, c-oryzanol) ${ }^{[48]}$, Lycopersicon esculentum extracts ${ }^{[49]}$, myristoleic acid from Malva verticillata seeds extract ${ }^{[50]}$, and Carthamus tinctorius extract ${ }^{[51]}$ are beneficial in the treatment of hair loss because of their property to stimulate KGF.

VEGF is a growth factor that stimulates vasculature and angiogenesis, thus stimulates hair growth accompanied by increases in hair follicles and hair size ${ }^{[52]}$. Asiasari radix extract ${ }^{[53]}$, Carthamus tinctorius extract ${ }^{[51]}$, and Chamaecyparis obtusa essential oils ${ }^{[54]}$ induced the expression of VEGF to promote hair growth.

IGF-1 is another growth factor vital for hair growth activity. It is produced in dermal papillae and plays 
www.ijpsonline.com

TABLE 1: HERBS WITH HAIR GROWTH PROMOTING ACTIVITY IN RODENT MODELS

\begin{tabular}{|c|c|c|c|c|}
\hline Plant source & Rodent species & Formulation & Mechanism of action & Reference \\
\hline Aconiti ciliare & C57BL/6 mice & Aqueous Extract & $\begin{array}{c}\text { Activation of Wnt/B-catenin signaling } \\
\text { pathway }\end{array}$ & [62] \\
\hline $\begin{array}{l}\text { Allium tuberosum } \\
\text { Rottler ex Spreng } \\
\text { extract }\end{array}$ & $\begin{array}{l}\text { Telogenic C57BL6/N } \\
\text { mice }\end{array}$ & Ethanol extract & $\begin{array}{c}\text { Increase the number of hair Follicles IGF-1 } \\
\text { Upregulation }\end{array}$ & [56] \\
\hline Asiasari radix & C57BL/6C3Hmice & Ethanol extract & $\begin{array}{l}\text { Regulation of cell growth and growth factor } \\
\text { gene expression VEGF upregulation }\end{array}$ & [53] \\
\hline Boehmeria nipononivea & Mice & Acetone extract & Inhibition of $5 a-$-reductase & [76] \\
\hline bergamot and boxthorn & Mice & Aqueous extract & $N A^{*}$ & [77] \\
\hline $\begin{array}{l}\text { Cercidiphyllum } \\
\text { japonicum }\end{array}$ & Mice & Methanol extract & $N A^{*}$ & [78] \\
\hline Chamaecyparis obtusa & C57BL/6mice & Essential Oils & Positive regulator of VEGF & [54] \\
\hline Crinum asiaticum & C57BL/6 mice & Ethanol extract & Proliferation of dermal papilla & [79] \\
\hline Cuscuta reflexa & Swiss albino rats & $\begin{array}{l}\text { Petroleum ether } \\
\text { and ethanol } \\
\text { extract }\end{array}$ & Promoting follicular proliferation & [80] \\
\hline Eclipta alba & C57/BL6mice & Methanol extract & $N A^{*}$ & [81] \\
\hline Eclipta alba extract & BALB/c Nude mice & $\begin{array}{l}\text { Petroleum ether } \\
\text { extract and } 3 \\
\text { different solvent } \\
\text { fractions in } \\
\text { vehicle mixture }\end{array}$ & $\begin{array}{l}\text { Increase in the number of follicular } \\
\text { keratinocytes in basal epidermal and matrix } \\
\text { cells, TGF-Bdownregulation }\end{array}$ & [29] \\
\hline Erica multiflora Linn. & Mice & Ethanol extract & $\begin{array}{l}\text { Promotion of dermal papilla cell growth and } \\
\text { cell cycle }\end{array}$ & [82] \\
\hline Fructus Panax ginseng & C57BL6mice & Ethanol extract & $\begin{array}{l}\text { Proliferation of dermal papilla cells through } \\
\text { anti apoptotic activation. }\end{array}$ & [35] \\
\hline Ginkgo biloba & $\mathrm{C} 3 \mathrm{Hmice}$ & Ethanol extract & $N A^{*}$ & [83] \\
\hline Hibiscus rosasinensis & Albino rat & $\begin{array}{l}\text { Petroleum ether } \\
\quad \text { extract }\end{array}$ & $N A^{*}$ & {$[84]$} \\
\hline Ishige sinicola & C57BL/6 mice & Ethanol extract & $\begin{array}{l}\text { 5a-reductase down regulation and Wnt/B- } \\
\text { catenin Upregulation }\end{array}$ & [61] \\
\hline $\begin{array}{l}\text { Lycopersicon } \\
\text { esculentum and } \\
\text { lycopene }\end{array}$ & C57BL/6 mice & $\begin{array}{l}\text { Ethyl acetate and } \\
\text { supercritical CO2 } \\
\text { extracts }\end{array}$ & $\begin{array}{l}\text { VEGF upregulation TGF-B downregulation } \\
\text { IGF-1 upregulation }\end{array}$ & [49] \\
\hline Lygodii spora & C57Black/6CrSlc mice & $\begin{array}{l}\text { Aqueous Ethanol } \\
\text { extract }\end{array}$ & Inhibition of $5 a-$ reductase & [85] \\
\hline Mentha piperita & C57BL/6 mice & Peppermint oil & IGF-1 upregulation & [55] \\
\hline Myricae Cortex & C57Black/6CrSlc mice & $\begin{array}{l}\text { Aqueous Ethanol } \\
\text { extract }\end{array}$ & Inhibition of 5a- Reductase & [86] \\
\hline Ocimum gratissum Linn. & $\begin{array}{l}\text { Sprague dawley rats } \\
\text { C57Black/6CrSlc mice }\end{array}$ & $\begin{array}{l}\text { Essential oil } \\
\text { Aqueous Ethanol } \\
\text { extract }\end{array}$ & Promoting follicular proliferation & [87] \\
\hline Piper nigrum & C57Black/6CrSlc mice & $\begin{array}{l}\text { Aqueous Ethanol } \\
\text { extract }\end{array}$ & 5a-reductase downregulation & [88] \\
\hline $\begin{array}{l}\text { Platycarya strobilacea } \\
\text { S. Et Z. }\end{array}$ & C57BL/6 mice & DMSO extract & $\begin{array}{c}\text { IGF-upregulation KGF- upregulation TGF-B1 } \\
\text { downregulation }\end{array}$ & [57] \\
\hline Polygonum multiflorum & C57BL/6Nmice & Aqueous extract & $\begin{array}{l}\text { Induction of B-catenin and Sonic hedgehog } \\
\text { (Shh) }\end{array}$ & [89] \\
\hline Puerariae Flos & $\begin{array}{l}\text { C57Black/6NCrSlc } \\
\text { mice }\end{array}$ & Ethanol extract & Inhibition of $5 a-$-reductase & [90] \\
\hline Schisandra nigra & C57BL/6mice & Ethanol extract & $\begin{array}{c}\text { Down regulation of TGF-B2, proliferation of } \\
\text { dermal papilla. }\end{array}$ & [71] \\
\hline Sophora flavescent & C57BL/6mice & Methanol extract & $\begin{array}{l}\text { Induction of mRNA levels of IGF-1 and KGF } \\
\text { in dermal papilla cells, inhibition of type II } \\
5 a-\text {-reductase }\end{array}$ & [91] \\
\hline
\end{tabular}


www.ijpsonline.com

\begin{tabular}{|c|c|c|c|c|}
\hline Tectona grandis Linn. & Albino mice & $\begin{array}{l}\text { Petroleum ether } \\
\text { Extract }\end{array}$ & $N A^{*}$ & [40] \\
\hline Thuja orientalis & C57BL/6N mice & Hot water extract & Wnt/B-catenin upregulation & [92] \\
\hline Zizyphus jujuba Linn. & $\mathrm{BALB} / \mathrm{c}$ mice & Essential oil & $N A^{*}$ & [38] \\
\hline Polyporus umbellatus & $\mathrm{C} 3 \mathrm{H} / \mathrm{He}$ mice & Methanol extract & $N A^{*}$ & [93] \\
\hline \multicolumn{5}{|l|}{ *Not available } \\
\hline \multicolumn{2}{|l|}{ Biological source } & Constituent & Category & References \\
\hline Polyporus umbellatus Fries & & -dihydroxybenzaldehyde & Terpenoids & [93] \\
\hline Polyporus umbellatus Fries & Acetos) & ringone and Polyporusterone & Steroids & [94] \\
\hline Capsicum annum & & Capsaicin & Alkaloid & [95] \\
\hline Apple & & ProcyanidinB-2 & Flavonoids & [96] \\
\hline Panax ginseng & & Ginsenoside Ro & Saponin & [64] \\
\hline Legume plants & & Isoflavone & Flavones & [97] \\
\hline Stephania cepharantha Hayata & & Bisbenzylisoquinoline & Alkaloid & [98] \\
\hline Puerariae Flos & Soya & saponin I, Kaikasaponin III & Saponin & [90] \\
\hline Crinum asiaticum & & orgalanthamine Nardin & Alkaloid Sesqueterpene & [79] \\
\hline Nardostachys jatamansi DC & & Jatamansic acid & Acid & [36] \\
\hline Zingiber officinale & & 6-Gingerol & Flavonoid & [43] \\
\hline \multicolumn{2}{|l|}{ Panax ginseng } & GinsenosideF2 & Saponin & [99] \\
\hline
\end{tabular}

an important role in the modulation of hair growth by regulating cellular proliferation and migration during hair follicle development. It has been proven that topical application of peppermint oil[ ${ }^{[55]}$, Allium tuberosum Rottler ex Spreng extract ${ }^{[56]}$, Platycarya strobilacea extract $^{[57]}$, and raspberry ketone from red raspberries (Rubus idaeus $)^{[58]}$ promoted IGF-1 production to positively impact hair growth activity.

EGF is expressed in the outer root sheath of hair follicles and stimulates cell propagation and formation of follicles ${ }^{[59]}$. Till to date, no preclinical studies using herbs have exclusively demonstrated promotion of EGF expression. Plants such as Carthamus tinctorius significantly augmented expression of hair growth promoting genes including VEGF, EGF, KGF and repressed the expression of hair growth inhibitory genes such as TGF- $\beta 1^{[51]}$.

$\beta$-catenin, the transducer of Wnt signaling, is critical for the development and growth of hair follicles ${ }^{[60]}$. It was found that Ishige sinicola extract and its active constituent octaphlorethol $\mathrm{A}^{[61]}$, Aconiti ciliare tuber extract $^{[62]}$ and Malva verticillata seeds extract ${ }^{[50]}$ have a potential to treat alopecia via activation of $\beta$-catenin pathway.

Blockage of hair growth inhibitory activity of dihydrotestosterone (DHT) or reduction in the synthesis of DHT via inhibition of $5 \alpha$-reductase activity are the principal mechanisms of herbs associated hair regrowth activity in AGA (Table 3). Both mechanisms are critical to reverse or abolish androgen dependent alopecia via inhibition of conversion of testosterone to DHT. Thujae occidentalis extract and linolenic acid ${ }^{[63]}$, Panax ginseng extracts and ginsenoside Ro ${ }^{[64]}$, Cuscuta reflexa extract ${ }^{[65]}$, natural flavonoids (myricetin, quercitin, baicalein, fisetin, biochanin A, daidzein, genistein, kaempferol) and polyphenolic compounds (alizarin, anthrarobin, gossypol, nordihydroguaiaretic acid, caffeic acid phenethyl ester, octyl and dodecyl gallates ${ }^{[66]}$ have efficacious effects of inhibition of $5 \alpha$-reductase activity and inhibition of conversion of testosterone to DHT in androgen dependent alopecia. Scutellaria baicalensis extract and its main component baicalin ${ }^{[67]}$, Rosmarinus officinalis extract and 12-methoxycarnosic acid ${ }^{[68]}$ and forsythiaside A derived from Forsythia suspensa ${ }^{[69]}$ inhibit the binding of DHT to androgen receptors. Androgen-inducible TGF- $\beta 1$ is a catagen phase inducer that mediates hair growth suppression ${ }^{[70]}$. Eclipta alba extract ${ }^{[29]}$, Schisandra nigra extract ${ }^{[71]}$, Carthamus tinctorius extract $^{[51]}$, and forsythiaside A derived from Forsythia suspens $a^{[69]}$ promoted hair growth via down-regulation of TGF- $\beta$ expression. Treatment of $\mathrm{HaCaT}$ cells with the TGF- $\beta 1$ inhibitors such as curcumin and apigenin resulted in a concentration-dependant decrease in TGF- $\beta 1$ expression ${ }^{[70]}$. Also $1 \%$ procyanidine B-2 from 
TABLE 3: APPROVED OR UNAPPROVED (IN CLINICAL DEVELOPMENT) COMPOUNDS FOR ANDROGENETIC ALOPECIA INDICATION

\begin{tabular}{|c|c|c|c|c|}
\hline Compound & Development stage & Route & Mechanism of action & Reference \\
\hline Cyproterone acetate & Clinical trial & Oral & Androgen receptor antagonist & [100] \\
\hline Dutasteride & $\begin{array}{l}\text { Approved in Japan } \\
\text { and South Korea }\end{array}$ & $\begin{array}{l}\text { Oral, topical, } \\
\text { mesotherapy }\end{array}$ & $5 a$-reductase 1 and 2 downregulation & [101] \\
\hline Finasteride & Approved in USA & $\begin{array}{l}\text { Oral, topical, } \\
\text { mesotherapy }\end{array}$ & 5a-reductase downregulation & [102] \\
\hline Fluridil & Clinical trial & Topical & Androgen receptor antagonist & [103] \\
\hline Melatonin & Clinical trial & Topical & Activates prostamide a F2 receptors & {$[104,105]$} \\
\hline Minoxidil & Approved in USA & Topical & Stimulates VEGF and PGE2 & {$[106]$} \\
\hline $\begin{array}{l}\text { Spironolactone } \\
\text { (Aldactone) }\end{array}$ & Clinical trial & Oral, topical & $\begin{array}{l}\text { Reduces adrenal androgen production and } \\
\text { competitively blocks androgen receptors }\end{array}$ & [107] \\
\hline Thymosin B4 & Clinical trial & Topical & Stimulates Hair Follicle stem cells & [108] \\
\hline Tretinoin & Clinical trial & Topical & Promotes vascular proliferation & [109] \\
\hline
\end{tabular}

apple reduced TGF- $\beta 1$ levels and helped in conversion of telogen follicles to anagen hair follicles ${ }^{[72]}$. PGD2 inhibition or PGE2 and PGF2 enhancement may be considered as a pharmacological mechanism for treating $\mathrm{AGA}^{[73]}$. Some active constituents from Chinese herbs such as ricinoleic acid, acteoside, amentoflavone, quercetin-3-O-rutinoside and hinokiflavone ${ }^{[74]}$ and soymetide- 4 derived from soy $\beta$-conglycinin ${ }^{[75]}$ were predicted to be prostaglandin D2 synthase inhibitors with high efficacy and good pharmacokinetic properties for hair loss indication.

Further research on herbal products may unravel more mechanisms to target future hair growth promoting therapies.

\section{CONCLUSION AND FUTURE RESEARCH DIRECTIONS}

Hair loss is an unmet medical condition requiring therapies that will provide sustained and long-term beneficial outcome. As an example, AGA affecting adult human population is largely relying on USFDAapproved treatments such as topical minoxidil, and oral finasteride. AA is another serious disorder characterized by nonscarring hair loss secondary to immune privilege breakdown at hair follicle region with life time prevalence in population of approximately $2 \%$. Noteworthy is, no USFDA-approved therapy exists for AA. Complementary and alternative medicine (CAM) is one approach to invent safe, natural, and efficacious remedies to restore hair. Most often, Phytotherapeutic products are used albeit, as supplements (not requiring regulatory approval). They claim heavily about hair growth and restoration potential however, at patients level the scenario is little different. Patients seem dissatisfied with treatment outcome as there are certain demerits associated with herbal preparations including inconsistent efficacy, lack of standardized processes to determine bioactive ingredients, and paucity of product research to support efficacy claims. There has never been a dearth of diverse rodent efficacy models utilized for studying human hair loss. On most occasions, animal research proved to be beneficial with vast potential for translatability to humans. This was possible owing to our comprehensive understanding of human hair ailments, and current knowledge of approved or unapproved therapies. The caveats seem to be not associated with rodent models, instead they appear to be associated with phytotherapeutic preparations warranting modifications in existing modalities, exploring novel chemical entities or rediscovering repurposed compounds that will be maximally efficacious and minimally adverse. Furthermore, adapting a conventional approach of using racemic mixtures of herbal preparations may add more uncertainty to efficacy for certain hair loss disorders requiring an extended duration of therapy. Investing more in characterizing herbal bioactive ingredients and synthesizing single active entities to potentially serve as monotherapy or polytherapy might be the key. Synthetic small molecules can be well characterized for a physicochemical composition, purity, efficacy, minimal efficacious concentration, and toxicity profile. Same set of parameters seem difficult to get evaluated for most herbal preparations due to bigger structural heterogeneity. Therefore, active small molecule synthetic entities will have a better recognition from regulatory agencies in chemistry, manufacturing, control (CMC) and animal model efficacy areas. In light of large diversity and availability of herbal classes of compounds already tested for hair loss indication, an enormous potential exists to generate a potent and stable synthetic small molecule remedy via incessant utilization of already established or newly developed rodent efficacy models. 


\section{Conflict of interests:}

The authors declared no conflict of interest.

\section{Acknowledgements:}

The authors are thankful to staff of APT Research

Foundation for their excellent editorial assistance.

\section{REFERENCES}

1. Porter RM. Mouse models for human hair loss disorders. $\mathbf{J}$ Anat 2003;202(1):125-31.

2. Schneider MR, Schmidt-Ullrich R, Paus R. The hair follicle as a dynamic miniorgan. Curr Biol 2009;19(3):R132-42.

3. Nakamura M, Sundberg JP, Paus R. Mutant laboratory mice with abnormalities in hair follicle morphogenesis, cycling, and/ or structure: annotated tables. Exp Dermatol 2001;10(6):36990.

4. Zhang H, Nan W, Wang S, Si H, Li G. Balance between fibroblast growth factor 10 and secreted frizzled-relate protein-1 controls the development of hair follicle by competitively regulating $\beta$-catenin signaling. Biomed Pharmacother 2018;103:1531-7.

5. Beardi B, Wanert F, Zöller M, Freyschmidt Paul P, Bodemer W, Kaup FJ. Alopecia areata in a rhesus monkey (Macaca mulatta). J Med Primatol 2007;36(3):124-30.

6. Novak MA, Meyer JS. Alopecia: possible causes and treatments, particularly in captive nonhuman primates. Comp Med 2009;59(1):18-26.

7. Tobin DJ. Characterization of hair follicle antigens targeted by the anti-hair follicle immune response. J Investig Dermatol Symp Proc 2003;8(2):176-181.

8. Xing L, Dai Z, Jabbari A, Cerise JE, Higgins CA, Gong W, et al. Alopecia areata is driven by cytotoxic T lymphocytes and is reversed by JAK inhibition. Nat Med 2014;20(9):1043-9.

9. Otberg N, Finner AM, Shapiro J. Androgenetic alopecia. Endocrinol Metab Clin North Am 2007;36(2):379-98.

10. Patel S, Sharma V, S Chauhan N, Thakur M, Dixit VK. Hair growth: focus on herbal therapeutic agent. Curr Drug Discov Technol 2015;12(1):21-42.

11. Hosking AM, Juhasz M, Mesinkovska NA. Complementary and alternative treatments for alopecia: a comprehensive review. Skin Appendage Disord 2019;5(2):72-89.

12. Harvey AL. Natural products in drug discovery. Drug Discov Today 2008;13(19-20):894-901.

13. Orasan MS, Roman II, Coneac A, Muresan A, Orasan RI. Hair loss and regeneration performed on animal models. Clujul Med 2016;89(3):327.

14. Santos Z, Avci P, Hamblin MR. Drug discovery for alopecia: gone today, hair tomorrow. Expert Opin Drug Discov 2015;10(3):269-92.

15. Gnann LA, Castro RF, Azzalis LA, Feder D, Perazzo FF, Pereira EC, et al. Hematological and hepatic effects of vascular epidermal growth factor (VEGF) used to stimulate hair growth in an animal model. BMC Dermatol 2013;13(1):15.

16. Uno $\mathrm{H}$. The stumptailed macaque as a model for baldness: effects of minoxidil. Int J Cosmet Sci 1986;8(2):63-71.

17. Müller-Röver S, Foitzik K, Paus R, Handjiski B, van der Veen $\mathrm{C}$, Eichmüller $\mathrm{S}$, et al. A comprehensive guide for the accurate classification of murine hair follicles in distinct hair cycle stages. J Invest Dermatol 2001;117(1):3-15.
18. Sun J, Silva KA, McElwee KJ, King Jr LE, Sundberg JP. The $\mathrm{C} 3 \mathrm{H} / \mathrm{HeJ}$ mouse and DEBR rat models for alopecia areata: review of preclinical drug screening approaches and results. Exp Dermatol 2008;17(10):793-805.

19. Sundberg JP, Cordy WR, King Jr LE. Alopecia areata in aging C3H/HeJ mice. J Invest Dermatol 1994;102(6):847-56.

20. McElwee KJ, Freyschmidt-Paul P, Sundberg JP, Hoffmann R. The pathogenesis of alopecia areata in rodent models. J Invest Dermatol Symp Proc 2003;8(1): 6-11.

21. Sundberg JP, McElwee K, Brehm MA, Su L, King Jr LE. Animal models for alopecia areata: what and where?. J Invest Dermatol Symp Proc 2015;17(2):23-26.

22. Paus R, Stenn KS, Link RE. The induction of anagen hair growth in telogen mouse skin by cyclosporine A administration. Lab Invest 198;60(3):365-9.

23. Wikramanayake TC, Rodriguez R, Choudhary S, Mauro LM, Nouri K, Schachner LA, et al. Effects of the Lexington Laser Comb on hair regrowth in the $\mathrm{C} 3 \mathrm{H} / \mathrm{HeJ}$ mouse model of alopecia areata. Lasers Med Sci 2012;27(2):431-6.

24. Yoon JS, Choi M, Shin CY, Paik SH, Kim KH, Kwon O. Development of a model for chemotherapy-induced alopecia: profiling of histological changes in human hair follicles after chemotherapy. J Invest Dermatol 2016;136(3):584-92.

25. Crabtree JS, Kilbourne EJ, Peano BJ, Chippari S, Kenney T, McNally $\mathrm{C}$, et al. A mouse model of androgenetic alopecia. Endocrinology 2010;151(5):2373-80.

26. Durward A, Rudall KM. Studies on hair growth in the rat. J Anat 1949;83(Pt 4):325.

27. Gilhar A, Keren A, Paus R. A new humanized mouse model for alopecia areata. J Invest Dermatol Symp Proc 2013;16(1):S37-S38.

28. Begum S, Gu LJ, Lee MR, Li Z, Li JJ, Hossain MJ, et al. In vivo hair growth-stimulating effect of medicinal plant extract on BALB/c nude mice. Pharm Biol 2015;53(8):1098-103.

29. Begum S, Lee MR, Gu LJ, Hossain J, Sung CK. Exogenous stimulation with Eclipta alba promotes hair matrix keratinocyte proliferation and downregulates TGF- $\beta 1$ expression in nude mice. Int J Mol Med 2015;35(2):496-502.

30. Lyle S, Christofidou-Solomidou M, Liu Y, Elder DE, Albelda $\mathrm{S}$, Cotsarelis $\mathrm{G}$. The $\mathrm{C} 8 / 144 \mathrm{~B}$ monoclonal antibody recognizes cytokeratin 15 and defines the location of human hair follicle stem cells. J Cell Sci 1998;111(21):3179-88.

31. Messenger AG, Rundegren J. Minoxidil: mechanisms of action on hair growth. Br J Dermatol 2004;150(2):186-94.

32. Kaufman KD, Dawber RP. Finasteride, a Type $25 \alpha$-reductase inhibitor, in the treatment of men with androgenetic alopecia. Expert Opin Investig Drugs 1999;8(4):403-15.

33. Takahashi T, Kamiya T, Yokoo Y. Proanthocyanidins from grape seeds promote proliferation of mouse hair follicle cells in vitro and convert hair cycle in vivo. Acta Derm Venereol 1998;78(6):428-32.

34. Yoshikawa M, Morikawa T, Kashima Y, Ninomiya K, Matsuda H. Structures of New Dammarane-Type Triterpene Saponins from the Flower Buds of Panax notoginseng and Hepato protective Effects of Principal Ginseng Saponins. J Nat Prod 2003;66(7):922-7.

35. Park S, Shin WS, Ho J. Fructus panax ginseng extract promotes hair regeneration in $\mathrm{C} 57 \mathrm{BL} / 6$ mice. $\mathrm{J}$ Ethnopharmacol 2011;138(2):340-4.

36. Gottumukkala VR, Annamalai T, Mukhopadhyay T. Phytochemical investigation and hair growth studies on the rhizomes of Nardostachys jatamansi DC. Pharmacogn Mag 
2011;7(26):146-50.

37. Dhanotia R, Chauhan NS, Saraf DK, Dixit VK. Effect of Citrullus colocynthis Schrad fruits on testosterone-induced alopecia. Nat Prod Res 2011;25(15):1432-43.

38. Yoon JI, Al-Reza SM, Kang SC. Hair growth promoting effect of Zizyphus jujuba essential oil. Food Chem Toxicol 2010;48(5):1350-4.

39. Roy RK, Thakur M, Dixit VK. Hair growth promoting activity of Eclipta alba in male albino rats. Arch Dermatol Res 2008;300(7):357-64.

40. Jaybhaye D, Varma S, Gagne N. Effect of Tectona grandis Linn. seeds on hair growth activity of albino mice. Int $\mathrm{J}$ Ayurveda Res 2010;1(4):211.

41. Murkute AV, Sahu MS, Mali PY, Rangari VD. Development and evaluation of formulations of microbial biotransformed extract of tobacco leaves for hair growth potential. Pharmacogn Res 2010;2(5):300.

42. Herman A, Herman AP. Topically used herbal products for the treatment of hair loss: preclinical and clinical studies. Arch Dermatol Res 2017;309(8):595-610.

43. Miao Y, Sun Y, Wang W, Du B, Xiao SE, Hu Y, et al. 6-Gingerol inhibits hair shaft growth in cultured human hair follicles and modulates hair growth in mice. PLoS One 2013;8(2):e57226.

44. Herman A, Herman AP. Mechanism of action of herbs and their active constituents used in hair loss treatment. Fitoterapia 2016;114:18-25.

45. du Cros DL. Fibroblast growth factor and epidermal growth factor in hair development. J Invest Dermatol 1993;101(1):S106-13.

46. Ozeki M, Tabata Y. Promoted growth of murine hair follicles through controlled release of basic fibroblast growth factor. Tissue Eng 2002;8(3):359-66.

47. Hébert JM, Rosenquist T, Götz J, Martin GR. FGF5 as a regulator of the hair growth cycle: evidence from targeted and spontaneous mutations. Cell 1994;78(6):1017-25.

48. Choi JS, Jeon MH, Moon WS, Moon JN, Cheon EJ, Kim JW, et al. In vivo hair growth-promoting effect of rice bran extract prepared by supercritical carbon dioxide fluid. Biol Pharm Bull 2014;37(1):44-53.

49. Choi JS, Jung SK, Jeon MH, Moon JN, Moon WS, Ji YH, et al. Effects of Lycopersicon esculentum extract on hair growth and alopecia prevention. J Cosmet Sci 2013;64(6):429-43.

50. Lee EY, Choi EJ, Kim JA, Hwang YL, Kim CD, Lee MH, et al. Malva verticillata seed extracts upregulate the Wnt pathway in human dermal papilla cells. Int J Cosmet Sci 2016;38(2):14854.

51. Junlatat J, Sripanidkulchai B. Hair growth-promoting effect of Carthamus tinctorius floret extract. Phytother Res 2014;28(7):1030-6.

52. Yano K, Brown LF, Detmar M. Control of hair growth and follicle size by VEGF-mediated angiogenesis. J Clin Invest 2001;107(4):409-17.

53. Rho SS, Park SJ, Hwang SL, Lee MH, Kim CD, Lee IH, et al. The hair growth promoting effect of Asiasari radix extract and its molecular regulation. J Dermatol Sci 2005;38(2):89-97.

54. Lee GS, Hong EJ, Gwak KS, Park MJ, Choi KC, Choi IG, et al. The essential oils of Chamaecyparis obtusa promote hair growth through the induction of vascular endothelial growth factor gene. Fitoterapia 2010;81(1):17-24.

55. Oh JY, Park MA, Kim YC. Peppermint oil promotes hair growth without toxic signs. Toxicol Res 2014;30(4):297-304.

56. Park KM, Kim DW, Lee SH. Extract of Allium tuberosum
Rottler ex Spreng promoted the hair growth through regulating the expression of IGF-1. Evid Based Complement Alternat Med 2015;2015.

57. Kim EJ, Choi JY, Park BC, Lee BH. Platycarya strobilacea S. et $\mathrm{Z}$. extract has a high antioxidant capacity and exhibits hair growth-promoting effects in male C57BL/6 mice. Prevent Nutr Food Sci 2014;19(3):136.

58. Harada N, Okajima K, Narimatsu N, Kurihara H, Nakagata $\mathrm{N}$. Effect of topical application of raspberry ketone on dermal production of insulin-like growth factor-I in mice and on hair growth and skin elasticity in humans. Growth Hormone IGF Res 2008;18(4):335-44.

59. Hansen LA, Alexander N, Hogan ME, Sundberg JP, Dlugosz A, Threadgill DW, et al. Genetically null mice reveal a central role for epidermal growth factor receptor in the differentiation of the hair follicle and normal hair development. Am J Pathol 1997;150(6):1959.

60. Huelsken J, Vogel R, Erdmann B, Cotsarelis G, Birchmeier W. $\beta$-Catenin controls hair follicle morphogenesis and stem cell differentiation in the skin. Cell. 2001;105(4):533-45.

61. Kang JI, Kim EJ, Kim MK, Jeon YJ, Kang SM, Koh YS, et al. The promoting effect of Ishige sinicola on hair growth. Marine drugs 2013;11(6):1783-99.

62. Park PJ, Moon BS, Lee SH, Kim SN, Kim AR, Kim HJ, et al. Hair growth-promoting effect of Aconiti Ciliare Tuber extract mediated by the activation of $\mathrm{Wnt} / \beta$-catenin signaling. Life Sci 2012;91(19-20):935-43.

63. Park WS, Lee CH, Lee BG, Chang IS. The extract of Thujae occidentalis semen inhibited $5 \alpha$-reductase and androchronogenetic alopecia of B6CBAF1/j hybrid mouse. J Dermatol Sci 2003;31(2):91-8.

64. Murata K, Takeshita F, Samukawa K, Tani T, Matsuda H. Effects of ginseng rhizome and ginsenoside Ro on testosterone $5 \alpha$-reductase and hair re-growth in testosterone-treated mice. Phytother Res 2012;26(1):48-53.

65. Pandit S, Chauhan NS, Dixit VK. Effect of Cuscuta reflexa Roxb on androgen-induced alopecia. J Cosmet Dermatol 2008;7(3):199-204.

66. Hiipakka RA, Zhang HZ, Dai W, Dai Q, Liao S. Structureactivity relationships for inhibition of human $5 \alpha$-reductases by polyphenols. Biochem Pharmacol 2002;63(6):1165-76.

67. Kim AR, Kim SN, Jung IK, Kim HH, Park YH, Park WS. The inhibitory effect of Scutellaria baicalensis extract and its active compound, baicalin, on the translocation of the androgen receptor with implications for preventing androgenetic alopecia. Planta Med 2014;80(02/03):153-8.

68. Murata K, Noguchi K, Kondo M, Onishi M, Watanabe N, Okamura $\mathrm{K}$, et al. Promotion of hair growth by Rosmarinus officinalis leaf extract. Phytother Res 2013;27(2):212-7.

69. Shin HS, Park SY, Song HG, Hwang E, Lee DG, Yi TH. The androgenic alopecia protective effects of Forsythiaside-A and the molecular regulation in a mouse model. Phytother Res 2015;29(6):870-6.

70. Huh S, Lee J, Jung E, Kim SC, Kang JI, Lee J, et al. A cellbased system for screening hair growth-promoting agents. Arch Dermatol Res 2009;301(5):381.

71. Kang JI, Kim SC, Hyun JH, Kang JH, Park DB, Lee YJ, et al. Promotion effect of Schisandra nigra on the growth of hair. Eur J Dermatol 2009;19(2):119-25.

72. Kamimura A, Takahashi $\mathrm{T}$, Watanabe $\mathrm{Y}$. Investigation of topical application of procyanidin B-2 from apple to 
identify its potential use as a hair growing agent. Phytomed 2000;7(6):529-36.

73. Colombe L, Vindrios A, Michelet JF, Bernard BA. Prostaglandin metabolism in human hair follicle. Exp Dermatol 2007;16(9):762-9.

74. Fong $\mathrm{P}$, Tong $\mathrm{HH}, \mathrm{Ng} \mathrm{KH}$, Lao CK, Chong CI, Chao CM. In silico prediction of prostaglandin D2 synthase inhibitors from herbal constituents for the treatment of hair loss. J Ethnopharmacol 2015;175:470-80.

75. Tsuruki T, Takahata K, Yoshikawa M. Anti-alopecia mechanisms of soymetide- 4 , an immuno stimulating peptide derived from soy $\beta$-conglycinin. Peptides 2005;26(5):707-11.

76. Shimizu K, Kondo R, Sakai K, Shoyama Y, Sato H, Ueno T. Steroid $5 \alpha$-reductase inhibitory activity and hair regrowth effects of an extract from Boehmeria nipononivea. Biosci Biotechnol Biochem 2000;64(4):875-7.

77. Shao LX. Effects of the extract from bergamot and boxthorn on the delay of skin aging and hair growth in mice. Zhongguo Zhong yao za zhi 2003;28(8):766-9.

78. Towatari K, Yoshida K, Mori N, Shimizu K, Kondo R, Sakai K. Polyphenols from the heartwood of Cercidiphyllum japonicum and their effects on proliferation of mouse hair epithelial cells. Planta med 2002;68(11):995-8.

79. Kim SC, Kang JI, Kim MK, Hyun JH, Boo HJ, Park DB, et al. Promotion effect of norgalanthamine, a component of Crinum asiaticum, on hair growth. Eur J Dermatol 2010;20(1):42-8.

80. Patel S, Sharma V, Chauhan NS, Dixit VK. A study on the extracts of Cuscuta reflexa Roxb. in treatment of cyclophosphamide induced alopecia. DARU 2014;22(1):7.

81. Datta K, Singh AT, Mukherjee A, Bhat B, Ramesh B, Burman AC. Eclipta alba extract with potential for hair growth promoting activity. J Ethnopharmacol 2009;124(3):450-6.

82. Kawano M, Han J, Kchouk ME, Isoda H. Hair growth regulation by the extract of aromatic plant Erica multiflora. J Nat Med 2009;63(3):335-9.

83. Kobayashi N, Suzuki R, Koide C, Suzuki T, Matsuda H, Kubo M. Effect of leaves of Ginkgo biloba on hair regrowth in $\mathrm{C} 3 \mathrm{H}$ strain mice. Yakugaku zasshi 1993;113(10):718.

84. Adhirajan N, Kumar TR, Shanmugasundaram N, Babu M. In vivo and in vitro evaluation of hair growth potential of Hibiscus rosa-sinensis Linn. J Ethnopharmacol 2003;88(2-3):235-9.

85. Matsuda H, Yamazaki M, Naruto S, Asanuma Y, Kubo M. Anti-androgenic and hair growth promoting activities of lygodii spora (spore of Lygodium japonicum) I. Active constituents inhibiting testosterone $5 \alpha$-reductase. Biol Pharm Bull 2002;25(5):622-6.

86. Matsuda H, Yamazaki M, Matsuo K, Asanuma Y, Kubo M. Anti-androgenic activity of Myricae Cortex- Isolation of active constituents from bark of Myrica rubra. Biol Pharm Bull 2001;24(3):259-63.

87. Orafidiya LO, Agbani EO, Iwalewa EO, Adelusola KA, Oyedapo OO. Studies on the acute and sub-chronic toxicity of the essential oil of Ocimum gratissimum L. leaf. Phytomed 2004;11(1):71-6.

88. Hirata $\mathrm{N}$, Tokunaga $\mathrm{M}$, Naruto $\mathrm{S}$, Iinuma $\mathrm{M}$, Matsuda $\mathrm{H}$. Testosterone $5 \alpha$-reductase inhibitory active constituents of Piper nigrum leaf. Biol Pharm Bull 2007;30(12):2402-5.

89. Park HJ, Zhang N, Park DK. Topical application of Polygonum multiflorum extract induces hair growth of resting hair follicles through upregulating Shh and $\beta$-catenin expression in C57BL/6 mice. J Ethnopharmacol 2011;135(2):369-75.

90. Murata K, Noguchi K, Kondo M, Onishi M, Watanabe N,
Okamura $\mathrm{K}$, et al. Inhibitory activities of Puerariae Flos against testosterone $5 \alpha$-reductase and its hair growth promotion activities. J Nat Med 2012;66(1):158-65.

91. Roh SS, Kim CD, Lee MH, Hwang SL, Rang MJ, Yoon YK. The hair growth promoting effect of Sophora flavescens extract and its molecular regulation. J Dermatol Sci 2002;30(1):43-9.

92. Zhang NN, Park DK, Park HJ. Hair growth-promoting activity of hot water extract of Thuja orientalis. BMC Complement Alternat Med 2013;13(1):1-2.

93. Inaoka $Y$, Shakuya A, Fukazawa $H$, Ishida $H$, Nukaya $H$, Tsuji K, et al. Studies on active substances in herbs used for hair treatment. I. Effects of herb extracts on hair growth and isolation of an active substance from Polyporus umbellatus F. Chem Pharm Bull 1994;42(3):530-3.

94. Ishida H, Inaoka Y, Shibatani JI, Fukushima M, Tsuji K. Studies of the active substances in herbs used for hair treatment. II. Isolation of hair regrowth substances, acetosyringone and polyporusterone A and B, from Polyporus umbellatus Fries. Biol Pharm Bull 1999;22(11):1189-92.

95. Harada N, Okajima K, Arai M, Kurihara H, Nakagata N. Administration of capsaicin and isoflavone promotes hair growth by increasing insulin-like growth factor-I production in mice and in humans with alopecia. Growth Hormone IGF Res 2007;17(5):408-15.

96. Kamimura A, Takahashi T. Procyanidin B-3, isolated from barley and identified as a hair-growth stimulant, has the potential to counteract inhibitory regulation by TGF- $\beta 1$. Exp Dermatol 2002;11(6):532-41.

97. Zhao J, Harada N, Kurihara H, Nakagata N, Okajima K. Dietary isoflavone increases insulin-like growth factor-I production, thereby promoting hair growth in mice. $\mathrm{J}$ Nutr Biochem 2011;22(3):227-33.

98. Nakaoji K, Nayeshiro H, Tanahashi T, Su Y, Nagakura N. Bisbenzylisoquinoline alkaloids from Stephania cepharantha and their effects on proliferation of cultured cells from the murine hair apparatus. Planta Med 1997;63(05):425-8.

99. Shin HS, Park SY, Hwang ES, Lee DG, Song HG, Mavlonov GT, et al. The inductive effect of ginsenoside F2 on hair growth by altering the WNT signal pathway in telogen mouse skin. Eur J Pharmacol 2017;730:82-9.

100. Sinclair R, Wewerinke M, Jolley D. Treatment of female pattern hair loss with oral antiandrogens. $\mathrm{Br} \mathrm{J}$ Dermatol 2005;152(3):466-73.

101. Olszewska M, Rudnicka L. Effective treatment of female androgenic alopecia with dutasteride. J Drug Dermatol 2005;4(5):637.

102. Caserini M, Radicioni M, Leuratti C, Annoni O, Palmieri R. A novel finasteride $0.25 \%$ topical solution for androgenetic alopecia: pharmacokinetics and effects on plasma androgen levels in healthy male volunteers. Int J Clin Pharmacol Ther 2014;52(10):842-9.

103. Sovak M, Seligson AL, Kucerova R, Bienova M, Hajduch M, Bucek M. Fluridil, a rationally designed topical agent for androgenetic alopecia: first clinical experience. Dermatol Surg 2002;28(8):678-85.

104. Fischer TW, Burmeister G, Schmidt HW, Elsner P. Melatonin increases anagen hair rate in women with androgenetic alopecia or diffuse alopecia: results of a pilot randomized controlled trial. Br J Dermatol 2004;150(2):341-5.

105. Fischer TW, Trüeb RM, Hänggi G, Innocenti M, Elsner P. Topical melatonin for treatment of androgenetic alopecia. Int $\mathrm{J}$ Trichol 2012;4(4):236. 
106. Rossi A, Cantisani C, Melis L, Iorio A, Scali E, Calvieri S. Minoxidil use in dermatology, side effects and recent patents. Recent Pat Inflamm Allergy Drug Discov 2012;6(2):130-6.

107. Rathnayake D, Sinclair R. Innovative use of spironolactone as an antiandrogen in the treatment of female pattern hair loss. Dermatol Clin 2010;28(3):611-8.
108. Philp D, Nguyen M, Scheremeta B, St-Surin S, M. Villa A, Orgel A, et al. Thymosin $\beta 4$ increases hair growth by activation of hair follicle stem cells. The FASEB J 2004;18(2):1-6.

109. Bazzano GS, Terezakis N, Galen W, Topical tretinoin for hair growth promotion. J Am Acad Dermatol 1986;15(4):880-3. 